\title{
Serotonin revisited
}

\author{
Philip J. Cowen • Irwin Lucki
}

Received: 6 December 2010 /Accepted: 6 December 2010 /Published online: 22 December 2010

(C) Springer-Verlag 2010

Serotonin (5-HT) pathways in the brain continue to be an important target for psychotropic drug development as well as the object of studies aimed at understanding the pathophysiology of psychiatric and neurological disorders. The discovery of multiple receptor subtypes for serotonin has led to an explosion of research to identify correspondent functions. Thus, as further selective ligands are developed, the function of the various receptor subtypes can be probed and elucidated. In this special issue of psychopharmacology, the functions of serotonin are revisited in light of new tools and discoveries.

The arrival of new pharmacological tools introduces novel targets for the many behavioural effects linked with serotonin. 5- $\mathrm{HT}_{6}$ receptors are associated with cognition (Kendall et al. 2011), as well as antidepressant and anxiolytic effects (Carr et al. 2011), while $5-\mathrm{HT}_{4}$ receptors are linked to appetite suppression (Francis et al. 2011). New roles for serotonin receptor subtypes and modulators of serotonin transmission are suggested in animal models of aggressive behaviour (Takahashi et al. 2011).

Serotonin receptor subtypes may also play an important role in antipsychotic drug development targeted at improvements of cognition in schizophrenia (Meltzer et al. 2011). Of course, it is well known that $5-\mathrm{HT}_{2 \mathrm{~A}}$ receptor antagonist

\footnotetext{
P. J. Cowen $(\square)$

University Department of Psychiatry, Warneford Hospital, Oxford OX3 7JX, UK

e-mail: phil.cowen@psych.ox.ac.uk

I. Lucki

Department of Psychiatry, University of Pennsylvania, 125 South 31st Street, Room 2204,

Philadelphia, PA 19104, USA
}

properties are a prominent part of the pharmacological profile of many clinically used antipsychotic drugs, but how far this action contributes to therapeutic effects, needs clarification; this is explored in the study of Rasmussen et al. (2011). The role of serotonin receptors in substance abuse is highlighted in two papers. Serotonin receptors are shown to be involved in behavioural sensitization to cocaine (Zayara et al. 2011); and the reinstatement of cocaine-seeking behaviour, a model for treatment relapse, involves $5-\mathrm{HT}_{2 \mathrm{~A}}$ receptors in the frontal cortex (Pockros et al. 2011). Finally, dopamine transmission is important in both schizophrenia and substance abuse, and the differential roles of serotonin receptor subtypes in regulating dopamine transmission are reviewed (Navailles and De Deurwaerdére 2011).

Despite undoubted progress in animal experimental studies, clinical application of serotonin pharmacology has not yet lived up to its initial promise. While selective serotonin reuptake inhibitors (SSRIs) are the most widely used drugs worldwide for the treatment of depression and anxiety, their efficacy is widely regarded as modest in terms of achieving clinical remission (Anderson et al. 2008). Whether some SSRIs are more effective than others, has been a persistently rehearsed question to which the paper of $\mathrm{Ou}$ and colleagues (2011) addresses itself.

Perhaps more pertinent is the observation that newer serotonin agents have not supplanted the SSRIs in the treatment of anxiety and depression. The notion that combining an SSRI action with additional agonist or antagonist activity in serotonin receptor subtypes will improve efficacy and tolerance is intriguing (Carr and Lucki 2011) but not yet established in clinical populations. Clinically, the notion that clinical depression is caused by diminished serotonin function has clearly been an oversimplification. 
The best evidence for such, as effect comes from studies of tryptophan depletion (Ruhe et al. 2007), a technique, which was pioneered in humans through a seminal paper published 25 years ago in Psychopharmacology by Simon Young (Young et al. 1985). Tryptophan depletion continues to be an important technique for examining the role of serotonin pathways in human neuropsychology and in various clinical disorders, as shown by several papers published in this special issue.

The tryptophan depletion data in depression provide sufficient evidence for involvement of serotonin neurones to merit further investigation with new brain imaging techniques made possible by the development of labelled subtype selective serotonin ligands. Two examples of this approach are published in the current issue, and clear findings seem to emerge of changes in the serotonin transporter and 5- $\mathrm{HT}_{1 \mathrm{~B}}$ receptor (Selveraj et al. 2011; Murrough et al. 2011). However, it must be acknowledged that even state-of-the-art imaging methodology with highly selective ligands has not revealed a particularly consistent pattern of serotonin receptor abnormalities in major depression (Drevets et al. 2007; Parsey et al. 2010). The reason for this unsatisfactory state of affairs probably rests with issues such as clinical heterogeneity and the effects of previous drug treatment. Methodological factors, such as the precise choice of reference tissue, might also be a factor. Whatever is the cause, it has made it difficult to place the role of serotonin in the pathophysiology of depression on a sound experimental footing.

While we know much about the influence of serotonin on certain well-characterised behaviours, for example feeding and anxiety, a formulation of the overall neuropsychological function of serotonin pathways is still elusive, sometimes bringing to mind the memorable comment of Barry Jacobs that serotonin is involved in virtually everything, but responsible for nothing (Jacobs and Fornal 1995). More recently, a number of interesting ideas have been proposed, focusing on the effects of serotonin pathways to modify punished responding perhaps by acting in opposition to dopamine. Seen in this way, serotonin may modulate the affective impact of punishment-related signals and also promote response inhibition (Cools et al. 2007; Boureau and Dayan 2010). The paper by Fitzgerald (2011) provides an interesting development of this approach by examining the role of serotonin in prefrontal cortex in relation to noradrenaline.

Serotonin continues to be a vibrant research area with much left to discover about the physiological role and clinical importance of this fascinating neurotransmitter. A long road probably remains, but even psychopharmacologists can be encouraged by the reported comment of Albert Einstein: 'It's not that I'm so smart, it's just that I stay with problems longer.'
Acknowledgment PJC has been a paid member of boards that have advised different drug companies on the development of antidepressant drugs. In the last 3 years, these companies have included Eli Lilly, Lundbeck and Servier. He has also received remuneration for scientific advice given to legal representatives of GlaxoSmithKline. In the last 3 years, IL has been a paid member of the Neuroscience Scientific Advisory Board for Wyeth, received research support from Astra-Zeneca, and received remuneration for scientific advice given to legal representatives of Bristol-Myers Squibb.

\section{References}

Anderson IM, Ferrier IN, Baldwin RC, Cowen PJ, Howard L, Lewis G, Matthews K, McAllister-Williams RH, Peveler RC, Scott J, Tylee A (2008) Evidence-based guidelines for treating depressive disorders with antidepressants: a revision of the 2000 British Association for Psychopharmacology guidelines. J Psychopharmacol 22:343-396

Boureau Y-L, Dayan P (2010) Opponency revisited: competition and cooperation between dopamine and serotonin. Neuropsychopharmacology 36:74-97. doi:10.1038/npp.2010.151

Carr GV, Lucki I (2011) The role of serotonin receptor subtypes in treating depression: a review of animal studies. Psychopharmacology. doi:10.1007/s00213-010-2097-z (this issue)

Carr GV, Schechter LE, Lucki I (2011) Antidepressant and anxiolytic effects of selective $5-\mathrm{HT}_{6}$ receptor agonists in rats. Psychopharmacology. doi:10.1007/s00213-010-1798-7 (this issue)

Cools R, Roberts AC, Robbins TW (2007) Serotonergic regulation of emotional and behavioural control processes. Trends Cogn Sci $12: 31-40$

Drevets WC, Thase ME, Moses-Kolko EL, Price J, Frank E, Kupfer DJ, Mathis C (2007) Serotonin-1A receptor imaging in recurrent depression: replication and literature review. Nucl Med Biol 34:865-877

Fitzgerald PJ (2011) A neurochemical yin and yang: does serotonin activate and norepinephrine deactivate the prefrontal cortex? Psychopharmacology. doi:10.1007/s00213-010-1856-1 (this issue)

Francis HM, Kraushaar NJ, Hunt LR, Cornish JL (2011) Serotonin 5$\mathrm{HT}_{4}$ receptors in the nucleus accumbens are specifically involved in the appetite suppressant and not locomotor stimulant effects of MDMA ('ecstasy'). Psychopharmacology. doi:10.1007/s00213010-1982-9 (this issue)

Jacobs BL, Fornal CA (1995) Serotonin and behaviour: a general hypothesis. In: Bloom FE, Kupfer DJ (eds) Psychopharmacology: the fourth generation of progress. Raven, New York, pp 461470

Jun Ou J, Lei Xun G, Rong Wu R, Hua Li L, Sheng Fang M, Geng Zhang H, Ping XS, Guo Shi J, Du B, Qin yuan X, Ping Zhao J (2011) Efficacy and safety of escitalopram versus citalopram in major depressive disorder: a 6-week, multicenter, randomized, double-blind, flexible-dose study. Psychopharmacology. doi:10.1007/s00213-010-1822-y (this issue)

Kendall I, Slotten JA, Codony X, Burgueno J, Pauwels PJ, Vela JM, Fone KC (2011) E-6801, a 5-HT(6) receptor agonist, improves recognition memory by combined modulation of cholinergic and glutamatergic neurotransmission in the rat. Psychopharmacology. doi:10.1007/s00213-010-1854-3 (this issue)

Meltzer, H, Horiguchi M, Massey W (2011) The role of serotonin in the NMDA receptor antagonist models of psychosis and memory impairment. Psychopharmacology (in press and in this issue)

Murrough JW, Henry S, Hu J, Gallezot J-D, Planeta-Wilson B, Neumaier JF, Neumeister A (2011) Reduced ventral striatal/ 
ventral pallidal serotonin $n_{1 \mathrm{~B}}$ receptor binding potential in major depressive disorder. Psychopharmacology. doi:10.1007/s00213010-1881-0 (this issue)

Navailles S, De Deurwaerdére P (2011) Presynaptic control of serotonin on striatal dopamine function. Psychopharmacology. doi:10.1007/s00213-010-2029-y (this issue)

Parsey RV, Ogden RT, Miller JM, Tin A, Hesselgrave N, Goldstein E, Mikhno A, Milak M, Zanderigo F, Sullivan GM, Oquendo MA, Mann JJ (2010) Higher serotonin 1A binding in a second major depression cohort: Modelling and reference region considerations. Biol Psychiatry 68:170-178

Pockros LA, Pentkowski NS, Swinford SE, Neisewander JL (2011) Blockade of $5-\mathrm{HT}_{2 \mathrm{~A}}$ receptors in the medial prefrontal cortex attenuates reinstatement of cue-elicited cocaine-seeking behavior in rats. Psychopharmacology. doi:10.1007/s00213-010-2071-9 (this issue)

Rasmussen H, Ebdrup BH, Erritzoe D, Aggernaes B, Oranje B, Kalbitzer J, Pinborg LH, Baare WFC, Svarer C, Lublin H, Knudsen GM, Glenthoj B (2011) Serotonin2A receptor blockade and clinical effect in first-episode schizophrenia patients treated with quetiapine. Psychopharmacology. doi:10.1007/s00213-010-1941-5 (this issue)
Ruhe HG, Mason NS, Schene AH (2007) Mood is indirectly associated to serotonin, norepinephrine and dopamine levels in humans: a meta-analysis of monoamine depletion studies. Mol Psychiatry 12:331-359

Selveraj S, Venkatesha-Murthy N, Bhagwagar Z, Bose SK, Hinz R, Grasby PM, Cowen PJ (2011) Diminished brain 5-HT transporter binding in major depression: a positron emission tomography study with [(11)C]DASB. Psychopharmacology. doi:10.1007/ s00213-009-1660-y (this issue)

Takahashi A, Quadros IM, de Almeida RM, Miczek KA (2011) Brain serotonin receptors and transporters: initiation vs. termination of escalated aggression. Psychopharmacology. doi:10.1007/s00213010-2000-y (this issue)

Young SN, Smith SE, Pihl RO, Ervin FR (1985) Tryptophan depletion causes a rapid lowering of mood in normal males. Psychopharmacology 87:173-177

Zayara AE, McIver G, Valdivia PN, Lominac KD, McCreary AC, Szumlinski KK (2011) Blockade of nucleus accumbens 5-HT (2A) and 5-HT (2C) receptors prevents the expression of cocaine-induced behavioral and neurochemical sensitization in rats. Psychopharmacology. doi:10.1007/s00213-010-1996-3 (this issue) 